\title{
PERENCANAAN KEPERAWATAN DALAM KONSEP ASUHAN KEPERAWATAN DI RUMAH SAKIT
}

\author{
tasyahalawa1705@gmail.com
}

\section{Latar Belakang}

Perencanaan keperawatan atau biasa disebut intervensi keperawatan merupakan bagian dari proses keperawatan yaitu tahap ketiga. Setelah mengetahui diagnose keperawatan yang tepat untuk pasien, selanjutnya perawat menentukan dan mempersiapkan perencanaan keperawatan untuk diimplementasikan ketika memberi asuhan keperawatan. Perencanaan keperawatan yang dipersipakan oleh perawat tentunya harus berhbungan dengan kondisi pasien berdasarkan pengkajian dan diagnose keperawatan. Perencanaan keperawatan bagian dari proses keperawatan. Perencanaan keperawatan yang dipersiapakn dengan baik tentu akan memberikan pengaruh yang baik terhadap pelaksanaan tindakan yang dilakukan. Oleh karena itu perawat perlu mempersiapkan perencanaan yang baik karena akan menjadi acuan perawat untuk meberikan asuhan kepada pasien. Untuk dapat mempersiapkan perencanaan yang baik perawat harus mempunyai pengetahuan yang baik untuk menentukan tindakan keperawatan yang tepat pada pasien. Dalam melakukan setiap tindakan keperawatan perawat tidak boleh sembarang memberikan tindakan perlu didasari dasar ilmiah. Ini dilakukan agar asuhan ataupun pelayanan yang perawat berikan kepada pasien tepat dan tujuan dan kriteria hasil yang diharapkan.

Asuhan keperawatan di rumah sakit adalah suatu rangkaian kegiatan yang di berikan melalui praktek keperawatan kepada pasien di rumah sakit, untuk membantu menyelesaikan masalah kesehata tersebut dengan menggunakan pendekatan proses keperawatan. Dalam memberikan asuhan keperawatan dirumah sakit digunakan suatu pendekatan yang sistemik yaitu dengan keperawatan kesehatan. Pendekatan ini digunakan dalam rangka mengidentifikasi dan memecahkan masalah-masalah yang dihadapi pasien di rumah sakit dimulai dari pengkajian, penemuan diagnosa keperawatanpasien, perencanaan, pelaksanaan dan teknik evaluasi. Hal penting yang perlu diketahui terkait perencanaan keperawatan ini perawat perlu menentukan prioritas, menulis tujuan, dan merencanakan tindakan keperawatan tang akan dilakukan. Pada tahap menentukan prioritas perawat menentukaan masalah pasien yang terlebih dahulu diatasi. Diantara diagnosa keperawatan yang sudah ditentukan perawat harus bisa memprioritaskan hal yang terlebih dahulu 
dilakukan segera.

\section{Metode}

Metode penulisan yang digunakan dalam penulisan laporan ini adalah literature review. Literature review yang dilakukan berupa suumber sumber dari pustaka artikel penelitian. Artikel dipublikasikan secara elektronik dan diunduh melalui Google Scholar,science direct, scopus, ebook, dan dari beberapa buku keperawatan Desain pada penelitian ini penulis menggunakan desain deskriptif - analitik dengan pendekatan cross sectional, yang merupakan rancangan penelitian dengan melakukan pengukuran atau pengamatan terhadap perencanaan keperawatan dalam asuhan keperawatan di rumah sakit Penerapan Asuhan Keperawatan oleh perawat pelaksana yang terdiri dari beberapa komponen yaitu pengkajian keperawatan, diagnosa keperawatan, perencanaan keperawatan, implementasi dan evaluasi keperawatan Dikatakan kedalam kategori baik Proses asuhan keperawatan merupakan tugas dan kewajiban seorang perawat dari pasien datang sampai pasien pulang, dimulai dengan pengkajian secara menyeluruh, kemudian menegakkan diagnosa keperawatan dari data pengkajian tersebut, serta melaksanakan intervensi, implementasi dan evaluasi keefektifan diagnosa awal yang sudah ditegakkan.

Hasil

Jurnal dengan judul Perencanaan Asuhan Keperawatan di rumah sakit bertujuan untuk mengetahui tahapan perencanaan asuhan keperawatan di rumah sakit yang akan diberikan kepada klien agar pemenuhan pelayanan dapat berjalan dengan baik. Hasil nya adalah perencanaan asuhan keperawatan dikategorikan baik karena perencanaan keperawatan sangat penting pada asuhan keperawatan terhadap pasien sebelum melakukan tindakan. Judul dengan jurnal Pengetahuan Dan Sikap Perawat Terhadap Perencanaan Asuhan Keperawatan di rumah sakit . Tujuannya adalah untuk mendoorng perawat dan mahasiswa agar melakukan perencanaan keperawatan yang tepat sesuai dengan standar konsep dasar. Hasil dari data yang telah dikumpulkan dari berbagai sumber, banyak perawat yang telah melakukan perencanaan keperawatan dalam memberikan asuhan keperawatan yang tepat pada pasien. Jurnal dengan judul Pengetahuan Dan Sikap Perawat Terhadap Perencanaan Asuhan Keperawatan, bertujuan untuk mengetahui tentang perencanaan, asuhan keperawatan, dan mengapa pentingnya perencanaan dalam asuhan keperawatan. 
Hasil dari tahap perencanaan adalah untuk mengidentifikasi seluruh kebutuhan yang diperlukan klien. Kebutuhan ini menggambarkan masalah yang terjadi pada klienbaik actual maupun risiko Jurnal dengan judul Tahapan Perencanaan dalam Proses Asuhan Keperawatan bertujuan untuk mengetahui tahapan atau langkah-langkah dari perencanaan dalam proses asuhankeperawatan. Perencanaan Keperawatan merupakan suatu proses penyusunan berbagai intervensi keperawatan yang dibutuhkan untuk mencegah, menurunkan, atau mengurangi masalah-masalah klien. Perencanaan ini merupakan langkah ketiga dalam membuat suatu proses keperawatan. Langkah-langkah perencanaan yaitu sebagai berikut: Penentuan prioritas diagnosis, Penentuan tujuan dan hasil yang diharapkan. Untuk memudahkan dalam menentukan rencana tindakan.

Judul dengan jurnal Pentingnya Perencanaan Asuhan Keperawatan,bertujuan untuk memberi informasi kepada pembaca khususnya para perawat atau yang sedang mengikuti pendidikan keperawatan mengenai pentingnya perancanaan asuhan keperawatan sehingga asuhan keperawatan dapat dengan mudah dan cepat serta tepat untuk dilaksanakan. Hasil yang diperoleh menunjukkan bahwa perencaaan dalam asuhan keperawatan sangat perlu. Diagnosis Keperawatan merupakan keputusan klinik tentang respon individu, keluarga dan masyarakat tentang masalah kesehatan aktual atau potensial, dimana berdasarkan pendidikan dan pengalamannya, perawat secara akuntabilitas dapat mengidentifikasi dan memberikan intervensi secara pasti untuk menjaga, menurunkan, membatasi, mencegah dan merubah status kesehatan klien Proses asuhan keperawatan merupakan tugas dan kewajiban seorang perawat dari pasien datang sampai pasien pulang, dimulai dengan pengkajian secara menyeluruh, kemudian menegakkan diagnosa keperawatan dari data pengkajian tersebut, serta melaksanakan intervensi, implementasi dan evaluasi keefektifan diagnosa awal yang sudah ditegakkan Pelaksanaan asuhan keperawatan profesional diwujudkan dengan menerapkan model praktek keperawatan profesional (MPKP) disetiap ruangan.di RS .

Hasil dari pelayanan di rumah sakit dapat berupa output dan outcome. Output yang dihasilkan dari pelayanan tersebut merupakan jasa pelayanan yang diberikan oleh perawat kepada pasien. Sedangkann outcome yang dihasilkan dari pelayanan di rumah sakit merupakan tingkat kesembuhan yang didapat oleh pasien. Kedua hasil pelayanan tersebut sangat menentukan bagi indikator kualitas pelayanan sebuah rumah sakit. Fokus pemberian asuhan keperawatan ditujukan pada respon klien terhadap masalah-masalah kesehatan yang berhubungan dengan pemenuhan kebutuhan dasar manusia. Misalnya dapatkah klien melakukan aktivitas sehari-hari, sehingga fokus pengkajian klien adalah respon klien yang nyata maupun potensial terhadap masalah-masalah aktifitas harian proses dan nilai-nilai profesional), yang memfasilitasi perawat profesional, mengatur pemberian asuhan 
keperawatan termasuk lingkungan tempat asuhan keperawatan tersebut.

Perawat sebagai perencana keperawatan harus mampu mengkaji hingga mengevaluasi kesinambungan asuhan keperawatan, memberikan tindakan khusus untuk mengajarkan dalam mempertahankan atau memulihkan kembali kondisi pasien secara optimal dan bertanggung jawab untuk memastikan bahwa semua informasi yang sesuai telah disediakan untuk orang-orang yang akan terlibat dalam perawatan pasien, termasuk keluarganya Pasien yang tidak mendapat pelayanan sebelum pemulangan, terutama pasien yang memerlukan perawatan kesehatan dirumah, konseling kesehatan atau penyuluhan dan pelayanan komunitas akan kembali ke ruang kedaruratan dalam 24-48 jam.

\section{Pembahasan}

Perencanaan adalah suatu proses keperawatan yang meliputi pembuatan keputusan dan pemecahan masalah. Dalam perencanaan keperawatan, perawat menetapkan sesuai dengan hasil pengumpulan data pada tahap pengkajian serta rumusan diagnosa keperawatan yang merupakan tujuan awal dari asuhan keperawatan. Langkah-langkah dalam membuat perencanaan keperawatan adalah menetapkan prioritas masalah, menetapkan tujuan atau hasil yang di harapkan serta menentukan intervensi keperawatan yang tepat dalam rencana asuhan keperawatan.

Asuhan keperawatan adalah suatu pendekatan untuk pemecahan masalah pada pasien dengan memberikan pelayanan keperawatan. Rencana tindakan adalah suatu hal yang sangat penting dalam intervensi untuk membantu klien mencapai kesejahteraan dan kesehatan. Di butuhkan kesadaran perawat dalam menyusun perencanaan agar kinerja perawat semakin meningkat. Pengetahuan dan motivasi perawat juga berpengaruh, salah satu literature saya menunjukkan bahwa perawat yang memiliki pengetahuan yang tinggi mengenai proses keperawtan termasuk intervensi keperawatan akan dapat memeberikan pelayanan yang semakin baik kepada pasien. Semakin tinggi pengetahuan perawat maka akan semakin baik pula perawat menerapkan perencanaan yang telah dipersiapkan. Ini menunjukkan pengetahuan yang dimiliki perawat menentukan ketepatan perawat dalam memberikan pelayanan.

Rumah sakit merupakan sebuah organisasi kesehatan yang sangat bermanfaat guna memberikan pelayanan kesehatan bagi masyarakat, sebagaimana tertera dalam UU RI No 44 pasal 1). Setiap tenaga kesehatan yang bekerja dirumah sakit harus bekerja sesuai dengan standar profesi, standar pelayanan rumah sakit, standar prosedur operasional yang berlaku, etika profesi, menghormati hak pasien, dan mengutamakan keselamatan pasien. Tenaga kesehatan tersebut diantaranya tenaga medis dan penunjang medis, tenaga keperawatan, tenaga kefarmasian, tenaga manajemen rumah sakit dan tenaga non 
kesehatan UU RI No 44 pasal 12-13. Salah satu pelayanan kesehatan yang diberikan oleh tenaga kesehatan adalah pelayanan keperawatan, Sebagai bagian dari pelayanan kesehatan, maka pelayanan keperawatan yang dilakukan oleh tenaga perawatmemiliki tugas diataranya memberikan asuhan keperawatan.

Asuhan keperawatan adalah suatu pendekatan untuk pemecahan masalah yang memampukan perawat untuk mengatur dan memberikan asuhan keperawatan. Standar asuhan yang tercantum dalam Standar Praktik Klinis Keperawatan terdiri dari lima fase asuhan keperawatan: 1) Pengkajian; 2) Diagnosa; 3) Perencanaan; 4) Implementasi; dan 5) Evaluasi. Salah satu manfaat dari penerapan asuhan keperawatan yang baik adalah meningkatkan mutu dan kualitas pelayanan dalam bidang keperawatan permasalahan pelayanan keperawatan di negara Indonesia adalah banyaknya perawat yang belum melakukan asuhan keperawatan sesuai dengan standar. Di sebagian besar tatanan pelayanan keperawatan, masih terbatas melakukan kegiatan-kegiatan yang belum memenuhi kaedah asuhan keperawatan secara profesional yang bertanggung gugat tentang tingkat kepuasan pasien rawat inap terhadap asuhan keperawatan Kriteria pengkajian keperawatan meliputi: pertama pengumpulan data dilakukan dengan cara anamnesa, observasi, pemeriksaan fisik, serta pemeriksaan penunjang. Kedua, sumber data adalah pasien, keluarga atau orang yang terkait, tim kesehatan, rekam medik, dan catatan lain masa lalu, status kesehatan pasien saat ini, status bio, psiko, sosial spiritual, respon terhadap terapi. Harapan terhadap tingkat kesehatan yang optimal, resiko-resiko tinggi terhadap masalah. Kegiatan utama yang dilakukan dalam tahap pengkajian ini antara lain pengumpulan data, pengelompokan data, menganalisis data guna merumuskan diagnosis keperawatan.

Pekerja kesehatan di rumah sakit sangat bervariasi baik dari segi jenis maupun jumlahnya. Dalam melaksanakan tugasnya, pekerja rumah sakit banyak terpapar dengan berbagai faktor yang dapat menimbulkan dampak negatif dan mempengaruhi derajat kesehatan mereka. Mereka selalu berhubungan dengan berbagai bahaya potensial, dimana bila tidak diantisipasi dengan baik dan benar dapat mempengaruhi kesehatan dan keselamatan kerjanya. Rumah sakit yang merupakan salah satu pelayanan yang beroperasi 24 jam dimana pelayanan tersebut dilaksanakan oleh pekerja kesehatan rumah sakit. Pekerja kesehatan rumah sakit yang terbanyak adalah perawat yang berjumlah sekitar $60 \%$ dari tenaga kesehatan yang ada di rumah sakit. Perawat merupakan salah satu pekerja kesehatan yang selalu ada di setiap rumah sakit dan merupakan ujung tombak pelayanan kesehatan rumah sakit. Pekerjaan seorang perawat dalam memberikan pelayanan keperawatan tidak terlepas dari pengaturan jam kerja di suatu rumah sakit yang lebih dikenal dengan istilah shift kerja. 
Proses Asuhan Keperawatan yang terdiri dari 6 Standart, antara lain : 1. Pengumpulan data merupakan tahap awal proses keperawatan dan merupakan suatu proses yang sistematis dalam pengumpulan data dari berbagai sumber data untuk mengevaluasi dan mengidentifikasi status kesehatan klien 2. Diagnosa keperawatan keputusan klinik tentang respon individu, keluarga dan masyarakat tentang masalah kesehatan aktual atau potensial, sebagai dasar seleksi intervensi keperawatan untuk mencapai tujuan asuhan keperawatan sesuai dengan kewenangan perawat 3. Perencanaan (intervensi) keperawatan adalah semua tindakan asuhan yang perawat lakukan atas nama klien. Tindakan ini termasuk intervensi yang diprakarsai oleh perawat, dokter, atau intervensi kolaboratif 4. Pelaksanaan (implementasi) adalah pengelolaan dan perwujudan dari rencana keperawatan yang telah di susun pada tahap perencanaan 5. Evaluasi Keperawatan adalah perbandingan yang sistematik dan terencana tentang kesehatan klien dengan tujuan yang telah ditetapkan, dilaukan dengan cara bersinambungan dengan melibatkan klien dan tenaga kesehatan lainnya 6. Dokumentasi Keperawatan adalah informasi tertulis tentang status dan perkembangan kondisi klien serta semua kegiatan asuhan keperawatan yang dilakukan oleh perawat berhubungan dengan pemenuhan kebutuhan dasar manusia. Misalnya dapatkah klien melakukan aktivitas sehari-hari, sehingga fokus pengkajian klien adalah respon klien yang nyata maupun potensial terhadap masalah-masalah aktifitas harian.

Keperawatan merupakan suatu bentuk pelayanan profesional bersifat humanistik, menggunakan pendekatan holistik, dilakukan berdasarkan ilmu dan kiat keperawatan, berorientasi kepada kebutuhan objektif klien. Praktek keperawatan mengacu pada standar professional keperawatan dan menggunakan etika keperawatan sebagai tuntutan utama. Perawat dituntut untuk selalu melaksanakan Pengkajian adalah pemikiran dasar dari proses keperawatan mengumpulkan informasi atau data tentang klien agar dapat mengidentifikasi masalah-masalah yang dialami klien, mental, sosial dan lingkungan. Dokumentasi keperawatan dalam beberapa rumah sakit ditemukan bahwa kemampuan perawat mendokumentasikan hasil asuhan keperawatan rata-rata kurang dari 60\%. Selanjutnya dalam memberikan perawatan kesehatan pada keluarga pastinya akan terdapat hambatan baik dari keluarga maupun perawat. Hambatan dari keluarga terdiri dari pendidikan keluarga rendah, keterbatasan sumber daya, kebiasaankebiasaan yang salah, dan sosial budaya yang berlawanan dengan nilai-nilai keperawatan sedangkan dalam hambatan perawat terdiri dari sarana prasarana yang tidak menunjang, kondisi alam, kesulitan komunikasi, dan keterbatasan pengetahuan perawat tentang kultur keluarga. Dalam hambatan-hambatan ini seorang perawat tidak menjadikan alasan tidak melakukan proses keperawatan pada keluarga. Untuk itu proses keperawatan baik itu individu, keluarga, kelompok, dan masyarakat harus dilakukan untuk menunjang kesehatan yang lebih optimal.

Tahap perencanaan adalah suatu proses penyusunan sebagai intervensi 
keperawatan yang dibutuhkan dalam mencegah, mengurangi dan menurunkan angka masalah masalah yang ada pada klien atau pasien.Perencanaan ini merupakan langkah ketiga dalam membuat perencaan keperawatan. Dalam hal ini perawat membutuhkan pengetahuan serta keterampilan diantaranya pengetahuan tentang kekuatan dan kelemahan klien, nilai dan kepercayaan klien, batasan praktek keperawatan, peran dari tenaga kesehatan lainnya ,kemampuan dalam memecahkan masalah, mengambil keputusan, menulis tujuan serta memilih dan membuat strategi keperawatan yang aman dalam memenuhi tujuan, menulis instruksi keperawatan serta kemampuan dalam melaksanakan kerjasama dengan tingkat kesehatan lain

Motivasi yang baik yang di miliki perawat yaitu dapat melakukan tugas dengan cakap tanggap dan terlihat bersemangat. Hal ini terlihat dari pasien puas dengan pelayanan serta kinerja yang di berikan perawat saat memberikan asuhan keperawatan. Dalam asuhan keperawatan di butuhkan keterampilan dan kemampuan untuk mengatasi permasalahan yang timbul serta mampu malaksanakan tindakan keperawatan sesuai SOP yang ada. Menurut Sumijatun permasalahan pelayanan keperawatan di negara Indonesia adalah banyaknya perawat yang belum melakukan asuhan keperawatan sesuai dengan standar. Asuhan keperawatan adalah kerangka kerja dan struktur organisasi yang kreatif untuk memberikan pelayanan keperawatan, namun asuhan keperawatan juga cukup fleksibel untuk digunakan disemua lingkup keperawatan.

\section{Penutup}

Perencanaan adalah suatu proses keperawatan yang meliputi pembuatan keputusan dan pemecahan masalah. Dalam perencanaan keperawatan, perawat menetapkan sesuai dengan hasil pengumpulan data pada tahap pengkajian serta rumusan diagnosa keperawatan yang merupakan tujuan awal dari asuhan keperawatan. Langkah-langkah dalam membuat perencanaan keperawatan adalah menetapkan prioritas masalah, menetapkan tujuan atau hasil yang di harapkan serta menentukan intervensi keperawatan yang tepat dalam rencana asuhan keperawatan.

Asuhan keperawatan adalah suatu pendekatan untuk pemecahan masalah pada pasien dengan memberikan pelayanan keperawatan. Rencana tindakan adalah suatu hal yang sangat penting dalam intervensi untuk membantu klien mencapai kesejahteraan dan kesehatan. Di butuhkan kesadaran perawat dalam menyusun perencanaan agar kinerja perawat semakin meningkat. Pengetahuan dan motivasi perawat juga berpengaruh, salah satu literature saya menunjukkan bahwa perawat yang memiliki pengetahuan yang tinggi mengenai proses keperawtan termasuk intervensi keperawatan akan dapat memeberikan 
pelayanan yang semakin baik kepada pasien. Semakin tinggi pengetahuan perawat maka akan semakin baik pula perawat menerapkan perencanaan yang telah dipersiapkan. Ini menunjukkan pengetahuan yang dimiliki perawat menentukan ketepatan perawat dalam memberikan pelayanan.

Rencana asuhan keperawatan adalah petunjuk tertulis yang menggambarkan secara tepat mengenai rencana tindakan yang dilakukan terhadap klien sesuai dengan kebutuhannya berdasarkan diagnosis keperawatan. Rencana asuhan keperawatan ini bertujuan sebagai alat komunikasi antara sesama anggota perawatan dan antar tim kesehatan lainnya, untuk meningkatkan kesinambungan asuhan keperawatan terhadap klien, serta membantu dalam mendokumentasikan proses dan kriteria hasil asuhan keperawatan yang akan dicapai. Langkah langkah yang perlu di lakukan dalam konsep perencanaan keperawatan untuk memberi asuhan keperawata yang di inginkan yaitu dengan menetapkan urutan prioritas diagnosis keperawatan, kemudian menentukan tujuan asuhan keperawatan, selanjutnya menentukan rencana intervensi keperawatan, dan terakhir menuliskan rencana asuhan keperawatan. Dalam merumuskan tujuan, perawat harus merumuskan berdasarkan masalah atau diagnosis keperawatan, rumusan merupakan hasil akhir yang ingin di capai, harus bersifat objektif, tujuan perawat harus sejalan dengan tujuan klien, bisa mencakup tujuan masa pendek maupun panjang, mencakup kriteria keberhasilan dan dapat menjadi pedoman dari tindakan keperawatan dalam asuhan keperawatan.

\section{Daftar Pustaka}

1. Butar-Butar, J., \&Simamora, R. H. (2016). HubunganMutuPelayananKeperawatandengan Tingkat KepuasanPasienRawatInap di RSUD PandanKabupatenTapanuli Tengah. JurnalNers Indonesia, 6(1), 50-63.

2. Simamora , R. H . (2005).Hubungan Persepsi Perawat Pelaksana Terhadap Fungsi Pengorganisasian Yang Dilakukan oleh Kepala Ruangan Dengan Kinerja Ruang Rawat Inap RSUD Koja Jakarta Utara ( Doctoral dissertation, Tesis FIK UI, Tidakdipublikasikan).

3. Wijaya , Cipta Perdana . (2016). PENGARUH BURNOUT SYNDROME TERHADAP PROSES ASUHAN KEPERAWATAN (STUDI PADA PERAWAT RUMAH SAKIT MEDIKA UTAMA BLITAR) . JURNAL REVITALISASI Jurnal Ilmu Manajemen Vol. 5, Nomor (3)

4. Ratna Agustin. ( 2017 ). OPTIMALISASI PELAKSANAAN DISCHARGE PLANNING MELALUI PENGEMBANGAN MODEL DISCHARGE PLANNING TERINTEGRASI PELAYANAN KEPERAWATAN.Jurnal Keperawatan Muhammadiyah. Volume 2, Nomor (1)

5. Wirdah, H., \& Yusuf, M. (2016). Penerapan Asuhan Keperawatan oleh PerawatPelaksana di Rumah Sakit Banda Aceh. PSIK Unsyiah, Volume 1 Nomor (1), 1-6. 
6. Rof'i Muhamad., Tutik Sri Haryati., Pujasari Hening. (2012). Perjanjian dan Konsensus dalam Pelaksanaan Perencanaan Pulang Pada Perawat Rumah Sakit. Jurnal Keperawatan Indonesia. Volume 15 Nomor (3) . 2017-214.

7. Fatmawati, Astar \& Hasmin Tamsah, dkk. ( 2012 ). PENGARUH PELAYANAN ASUHAN KEPERAWATAN TERHADAP KEPUASAN PASIEN DI PUSKESMAS. JOURNAL OF MANAGEMENT Volume 1 Nomor (2)

8. Wijaya , Cipta Perdana . ( 2016 ). PENGARUH BURNOUT SYNDROME TERHADAP PROSES ASUHAN KEPERAWATAN (STUDI PADA PERAWAT RUMAH SAKIT MEDIKA UTAMA BLITAR) . JURNAL REVITALISASI Jurnal Ilmu Manajemen Vol.ume 5, Nomor (3)

9. Putri Wulandini S, Tri Krianto, dkk. ( 2016 ). FAKTOR-FAKTOR YANG BERHUBUNGAN DENGAN PENDOKUMENTASIAN ASUHAN KEPERAWATAN DI RUMAH SAKIT JIWA .NERS JURNAL KEPERAWATAN,Volume 12, Nomor (2)

10. Supratti, Ashriady . ( 2016 ) . PENDOKUMENTASIAN STANDAR ASUHAN KEPERAWATAN DI RUMAH SAKIT UMUM DAERAH MAMUJU, INDONESIA. Jurnal Kesehatan MANARANG . Volume 2, Nomor( 1), 2443-3861

11. Purnamasari, L. D., \& Ropyanto, C. B. (2012). Evaluasi Pelaksanaan Perencanaan Keperawatan . Jurnal Keperawatan Diponegoro Volume 1 Nomor (2) , 213-218.

12. Kasim, M., \& Abduroof, M. (2016, Mei). Peningakatan Kualitas Pelayanan dan Pendokumentasian Asuhan Keperawataqn dengan Metode TIM. Nurseline Journal, Volume 1Nomer (1), 62-72. 
10. Supratti, Ashriady . ( 2016 ). PENDOKUMENTASIAN STANDAR ASUHAN

KEPERAWATAN DI RUMAH SAKIT UMUM DAERAH MAMUJU, INDONESIA. Jurnal Kesehatan MANARANG . Volume 2, Nomor( 1), 2443-3861 
